
SUSUNAN DEWAN REDAKSI

“JURNAL NASIONAL KOMPUTASI DAN TEKNOLOGI INFORMASI (JNKTI)"

\author{
Penanggung Jawab \\ Muhammad Fadhli, S.Kom, M.Kom \\ Ketua Dewan Editor \\ Zulfan, ST, MT \\ Editor Pelaksana \\ Munawir, ST, MT \\ Baihaqi, ST, MT \\ Sekretaris \\ Yeni Yanti, ST, MT \\ Mitra Bestari \\ Prof. Dr. Ir. Yuwaldi Away, M.Sc \\ Dr. Taufiq A. Gani, S.Kom, M.Eng.Sc \\ Dr. Melinda, ST, M.Sc \\ Layout \\ Eka Novendra, ST \\ Penerbit \\ Program Studi Teknik Informatika \\ Universitas Serambi Mekkah \\ Alamat Penerbit
}

Gedung H Fakultas Teknik Universitas Serambi Mekkah

Jl. T. Imum Lueng Bata, Telp. (0651)26160 Batoh - Banda Aceh 


\section{SINOPSIS}

Jurnal Nasional Komputasi dan Teknologi Informasi (JNKTI) merupakan jurnal ilmiah nasional yang diterbitkan oleh Program Studi Teknik Informatika Universitas Serambi Mekkah yang mempublikasikan artikel-artikel ilmiah dalam bidang komputasi dan teknologi informasi.Jurnal ini terbit sebanyak 2 (dua) kali dalam 1 (satu) tahun yaitu pada Bulan April dan Oktober. Bidang-bidang fokus penelitian yang akan dipublikasi dalam jurnal ini antara lain :

- Bidang Rekayasa Perangkat Lunak

- Bidang Jaringan Komputer

- Bidang Multimedia dan Pengolahan Citra Digital

- Bidang Komputasi

- Multidisiplin ilmu lainnya yang relevan 
DAFTAR ISI

JNKTI VOL.2 NO.1, APRIL 2019

Studi Simulasi Aerodinamika Airfoil dan Prediksi

$1-8$

Performa Picth Tetap Turbin Angin Poros Tegak (Darrieus)

terhadap Output Power untuk Aplikasi Kecepatan Angin Rendah

Wahyu Priyanto ${ }^{1}$, Ira Devi Sara ${ }^{2}$, Rakhmad Syafutra Lubis ${ }^{3}$

Analisis Performansi Video Streaming Dengan Menggunakan

$9-12$

Protokol RTSP Pada Jaringan IEEE 802.11n

Rahmad Rizki ${ }^{1}$, Rizal Munadi ${ }^{2}$, Syahrial $^{2}$

Pengaruh Heatsink Terhadap Kinerja Modul Surya

$13-18$

T. Mizan Sya'rani D. ${ }^{1 *}$, Ira Devi Sara ${ }^{2}$, dan Laina Hilma Sari ${ }^{3}$

Penentuan Tingkat Penyebaran Ikan Berdasarkan Citra

Suhu Permukaan Laut Di Perairan Laut Kabupaten Aceh Jaya

Menggunakan Satelit Aqua Modis

Naziran ${ }^{1}$, Rizal Munadi ${ }^{2}$, Muchlisin ${ }^{2}$

Studi Pengaruh Hibridisasi Seleksi Roullete Wheel Dengan $26-30$

Tournament Selection Menggunakan Algoritma Berevolusi Pada TSP

Cut lilis Setiawati ${ }^{1}$, Taufiq Abdul Gani ${ }^{2}$, Yuwaldi Away ${ }^{2}$

Audit Dan Optimasi Energi Listrik Pada Bangunan Kampus $31-37$

Menggunakan Metode Algoritma Genetika

Samsuddin $^{1}$, Suriadi ${ }^{2}$, Yuwaldi Away ${ }^{3}$

Aplikasi Histogram Discrete Cosine Transform (DCT) Untuk $38-42$

Sistem Temu Kembali Citra Termal Berbasis Konten

Faridah $^{1}$, Khairul Munadi ${ }^{2}$, Fitri Arnia ${ }^{3}$

Pengujian Algoritma Artificial Neural Network (ANN) $43-47$

Untuk Prediksi Kecepatan Angin

Syukri $^{1}$, Samsuddin ${ }^{2}$

Penerapan Information Retrieval Menggunakan Pemodelan $48-54$

Topik Pada Deskripsi Portal Multimedia

Indra Gita Anugrah ${ }^{1}$ dan Harunur Rosyid ${ }^{2}$

Analisa Steganografi untuk Citra Bewarna (RGB)

Menggunakan Metode Less Significant Bit (LSB)

Raihan Islamadina $^{1}$, Baihaqi $^{2}$, dan Mauzar sulistriadi ${ }^{3}$ 


\title{
Audit Dan Optimasi Energi Listrik Pada Bangunan Kampus Menggunakan Metode Algoritma Genetika
}

\author{
Samsuddin $^{1}$, Suriadi ${ }^{2}$, Yuwaldi Away ${ }^{3}$ \\ 1,2,3 Magister Teknik Elektro, Universitas Syiah Kuala \\ Program Studi Teknik Elekro dan Komputer \\ Fakultas Teknik Universitas Syiah Kuala \\ *Koresponden email: samsuddin@ @erambimekkah.ac.id
}

\begin{abstract}
Abstrak - Pengelolaan dan pemanfaatan energi secara efesien dengan nilai yang rasional merupakan suatu kebutuhan yang perlu dipertimbangkan tanpa mengurangi fungsi dasar pada bagian yang benar-benar diperlukan. Mengacu pada keputusan Menteri Pendidikan Nasional No. 13 tahun 2012 tentang Penghematan Pemakaian Tenaga Listrik, Fakultas Teknik Unversitas Serambi Mekkah sebagai lembaga pendidikan memandang perlu untuk mengambil langkah konkrit terhadap penerapan keputusan menteri tersebut. Merujuk pada data pembayaran rekening listrik per bulan dapat diketahui bahwa penggunaan energi listrik rata-rata sebesar $3.059 \mathrm{kWh} /$ bulan, dengan biaya rata-rata sebesar Rp. 3.036 .333 per bulan di tahun 2016. Berdasarkan data pembayaran yang ditampilkan dalam bentuk tagihan rekening diperlukan suatu kajian berupa audit terhadap energi yang digunakan, sehingga dapat ditentukan langkah-langkah penghematan terhadap penggunaan energi listrik pada gedung tersebut. Langkah-langkah efesiensi yang dapat dilakukan seperti menggunakan optimalisasi penggunaan ruang dengan peralatan yang hemat energi, dan dari sisi sumber daya manusia dengan memberikan pedoman perilaku hemat energi. Hasil dari audit energi dapat dijadikan pendoman dalam rangka mendukung program efesiensi penggunaan energi listrik pada gedung Fakultas Teknik Universitas Serambi Mekkah. Tujuan utama penelitian melakukan audit dan analisis terkait nilai Intensitas Konsumsi Energi (IKE) berdasarkan data historis tahunan. Kemudian berdasarkan IKE akan dikenali Peluang Hemat Energi (PHE) dengan mengkombinasikan alat sensor infrared dengan algoritma genetika (AG), lalu mengimplementasikan pada gedung Fakultas Teknik Universitas Serambi Mekkah dalam bentuk nilai IKE optimum. Berdasarkan hasil penelitian, maka dapat di ambil kesimpulan bahwa dengan menggunakan metode algoritma genetika (AG) mendapatkan hasil penggunaan energi yang lebih optimal sebesar 45,65\% sesuai dengan IKE, dan juga memberikan Peluang Hemat Energi (PHE) dengan penerapan alat bantu sensor infrared.
\end{abstract}

Kata kunci : Algoritma Genetika, Intensitas Konsumsi Energi, Peluang Hemat Energi, Sersor Infrared

\section{Pendahuluan}

Pengelolaan dan pemanfaatan energi secara efesien dengan nilai yang rasional merupakan suatu kebutuhan yang perlu dipertimbangkan tanpa mengurangi fungsi dasar pada bagian yang benarbenar diperlukan. Instruksi presiden Nomor 10 tahun 2005 dan peraturan presiden Nomor 5 tahun 2006 mengeluarkan ketentuan dalam bentuk peraturan mengenai konversi energi. Peraturan ini bertujuan untuk pengelolaan energi listrik secara efesien dan efektif di lingkungan lembaga pemerintahan maupun swasta. Berdasarkan instruksi presiden tersebut, selanjutnya dikeluarkan Peraturan Menteri Energi Sumber Daya Manusia (ESDM) Nomor 031 tahun 2005 yang mengatur tata cara pelaksanaan hemat energi yang mengatur secara lebih terinci pemakaian energi, seperti pengurangan waktu penggunaan Air Conditioner (AC). Di lingkungan lembaga pendidikan, peraturan ini dijadikan rujukan untuk mengawasi penggunaan energi seperti yang telah di gagas oleh Kementrian Pendidikan Nasional yang telah dimulai dari tahun 1991 [1].

Mengacu pada keputusan Menteri Pendidikan Nasional No. 13 tahun 2012 tentang Penghematan Pemakaian Tenaga Listrik, Fakultas Teknik Unversitas Serambi Mekkah sebagai lembaga pendidikan memandang perlu untuk mengambil langkah konkrit terhadap penerapan keputusan menteri tersebut. Permasalahan yang terjadi hingga saat ini adalah tidak tersedianya data konsumsi energi pada gedung Fakultas Teknik Universitas Serambi Mekkah yang menggambarkan tingkat penggunaan energi listrik. Merujuk pada data pembayaran rekening listrik per bulan dapat diketahui bahwa penggunaan energi listrik rata-rata sebesar 3.059 $\mathrm{kWh} /$ bulan, dengan biaya rata-rata sebesar Rp. 3.036.333 per bulan di tahun 2016. Berdasarkan data pembayaran yang ditampilkan dalam bentuk tagihan rekening diperlukan suatu kajian berupa audit terhadap energi yang digunakan, sehingga dapat ditentukan langkah-langkah penghematan terhadap penggunaan energi listrik pada gedung tersebut [2].

Intensitas Konsumsi Energi Listrik (IKE) merupakan parameter yang dijadikan pedoman perlu tidaknya dilakukan audit terhadap penggunaan energi pada gedung Fakultas Teknik Universitas Serambi Mekkah. Langkah-langkah efesiensi yang dapat dilakukan seperti menggunakan optimalisasi penggunaan ruang dengan peralatan yang hemat energi, dan dari sisi sumber daya manusia dengan memberikan pedoman perilaku hemat energi. Hasil dari audit energi dapat dijadikan pendoman dalam 
rangka mendukung program efesiensi penggunaan energi listrik pada gedung Fakultas Teknik Universitas Serambi Mekkah, dengan menggunakan descriptive research method yang bertujuan untuk menemukan solusi dari masalah yang dihadapi saat ini [3].

Berdasarkan latar belakang, maka penelitian ini bertujuan untuk melakukan audit dan analisis terkait nilai Intensitas Konsumsi Energi (IKE) berdasarkan data historis tahunan. Kemudian berdasarkan IKE akan dikenali Peluang Hemat Energi (PHE) dengan mengkombinasikan alat sensor infrared dengan algoritma genetika (AG), lalu mengimplementasikan pada gedung Fakultas Teknik Universitas Serambi Mekkah dalam bentuk nilai IKE optimum.

\section{Tinjauan Pustaka}

Manajemen energi merupakan program terencana yang bertujuan untuk mengurangi anggaran biaya pengeluaran energi pada suatu bangunan. Awal mula manajemen energi adalah dengan menyelaraskan strategi perusahaan dengan penerapan manajemen energi, dengan demikian seluruh karyawan akan dapat berkomitmen terhadap penghematan energi di suatu instansi atau perusahaan. Undang-undang Energi Nomor 30 tahun 2007 dan Peraturan Pemerintah Nomor 70 tahun 2009 tentang konservasi energi menjabarkan konservasi energi adalah sebagai upaya sistematis, terencana dan terpadu guna melestarikan sumberdaya energi dalam negeri serta meningkatkan efisiensi pemanfaatannya [4].

Konservasi energi tidak selalu diartikan sebagai penggunaan energi sekecil mungkin, namun juga merupakan pengaturan pengeluaran biaya untuk konsumsi energi serendah mungkin. Konservasi energi juga dapat di definisikan sebagai penggunaan energi, sumber energi atau sumber daya energi secara efisien dan rasional tanpa mengurangi penggunaan energi yang memang benar-benar diperlukan dengan tidak menurunkan fungsi energi itu sendiri baik secara teknis maupun ekonomis. Efesiensi energi listrik dapat diterapkan secara bertingkat, mulai dari sistem pembangkitan, transmisi, sampai dengan pemanfaatan [5].

Penghematan biaya tagihan energi adalah hal yang sangat menarik bagi bisnis, industri maupun individu. Sebagian besar para pebisnis menghabiskan pendapatan mereka untuk membayar tagihan penggunaan energi, sehingga mereka termotivasi untuk mengawali dan terus melakukan program pengontrolan pemakaian penggunaan energi. Beberapa kasus, program pengontrolan penggunaan energi menghasilkan pengurangan konsumsi energi dan pengurangan emisi serta polusi lingkungan. Audit energi merupakan suatu proses analisis atau penelitian terhadap penggunaan energi pada suatu tempat yang menggunakan energi. Proses audit dimulai dari pengumpulan informasi aktivitas operasional fasilitas serta catatan tagihan utility dimasa lalu. Data ini kemudian dianalisa untuk mendapatkan gambaran tentang bagaimana fasilitas menggunakan energi, fasilitas yang menggunakan energi, dan peralatan konsumsi energi yang dapat menghemat pengeluaran biaya untuk pembayaran tagihan listrik serta membantu auditor mempelajari area-area apa saja yang harus diteliti untuk mengurangi pengeluaran energi [6].

Audit energi tidak terlepas dari standarisasi yang digunakan oleh negara dalam melakukan audit atau pengukuran. Standar yang digunakan dalam audit energi harus mengikuti aturan yang berlaku umum yang dipakai secara Internasional. Indonesia sendiri telah memiliki standar yang telah disesuaikan dengan keadaan iklim atau tekstur wilayah Indonesia, yaitu Standar Nasional Indonesia (SNI) [4].

Intensitas Konsumsi Energi (IKE) merupakan pembagian antara nilai konsumsi energi terhadap satuan luas bangunan gedung. Istilah ini digunakan untuk mengetahui tingkat penggunaan energi pada suatu bangunan, yang merujuk pada penggunaan energi listrik. pengelolaan terhadap energi listrik dilakukan dengan segala cara yang bertujuan untuk mengatur dan mengelola energi seefesien mungkin pada suatu bangunan tanpa mengurangi tingkat kenyamanan dan produktivitas. Peluang Hemat Energi (PHE) adalah cara yang mungkin dilakukan untuk mengurangi pemborosan energi.

Algoritma genetika merupakan suatu metode optimasi yang dapat digunakan untuk menentukan parameter kontrol optimal untuk suatu proses tertentu. Kelebihan algortima genetika diantaranya dapat digunakan untuk variabel diskrit maupun kontinyu dengan jumlah yang besar. Hasil akhir berupa beberapa variabel optimum dalam jumlah jamak dan optimasi dilakukan menggunakan coding variabel berupa data numerik, data ekperimen atau fungsi analitik [7].

Terdapat tiga aspek penting pada penggunaan algoritma genetika, jika telah didefinisikan maka algoritma genetika akan bekerja dengan baik, waluapun tentu saja algoritma genetika bukanlah solusi terbaik untuk memecahkan segala masalah. Algoritma genetika dimulai dengan sekumpulan set status yang dipilih secara random disebut populasi. Algoritma ini melakukan kombinasi terhadap dua populasi induk, dan setiap status atau individual di representasikan sebagai sebuah string.

\section{Metode Penelitian}

Penelitian dilakukan melalui tindakan atau aksi, tujuannya mengembangkan pendekatan atau keterampilan baru sehingga dapat diterapkan dan dikaji hasilnya secara langsung. Metode penelitian dapat dilihat pada Gambar 1. 


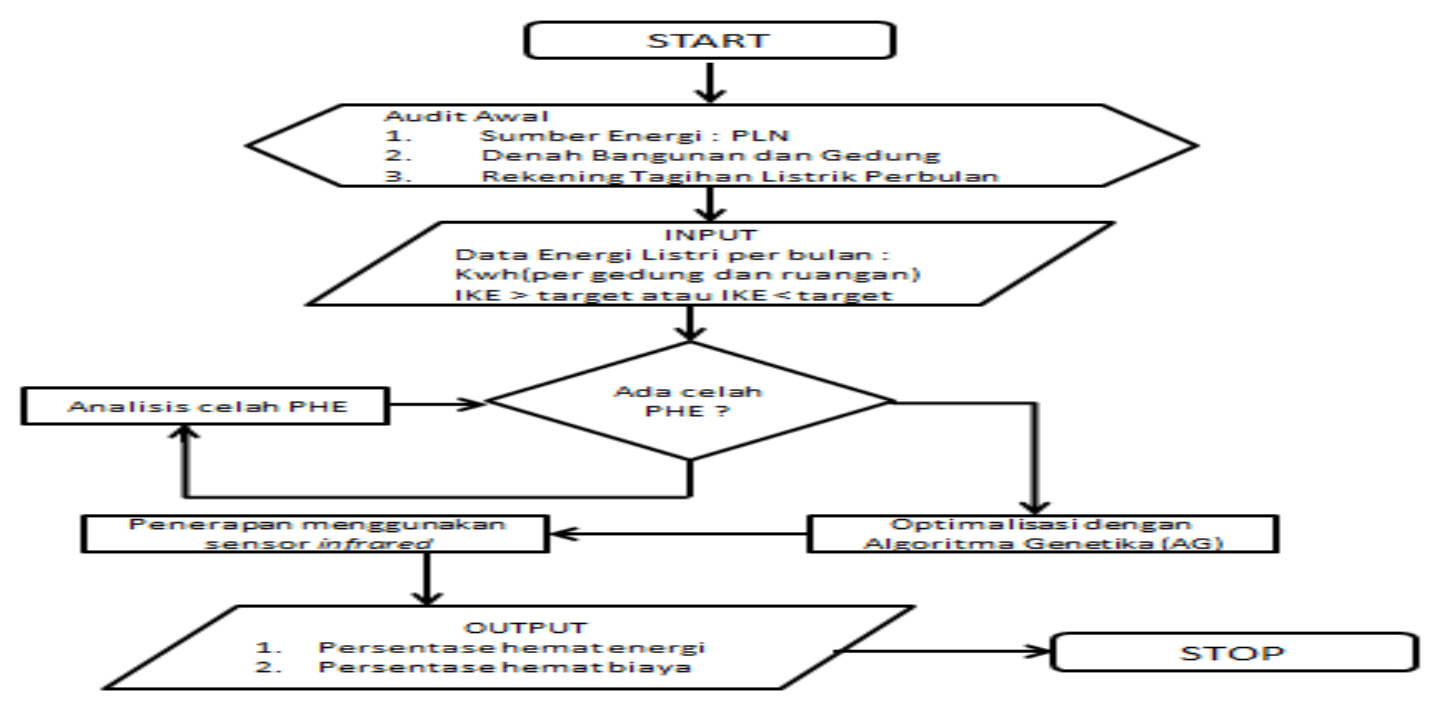

Gambar 1. Metode penelitian

\subsection{Tahapan Algoritma Genetika}

Langkah - langkah yang dilakukan dalam algoritma berevolusi untuk pengoptimalan pemakaian energi listrik adalah sebagai berikut :

1. Inisialisasi Populasi

2. Evaluasi individu

3. Seleksi
4. Crossover

5. Mutasi

Flowchart proses optimasi pemakaian energi listrik dengan menggunakan Algoritma Genetika dapat dilihat pada Gambar 2.

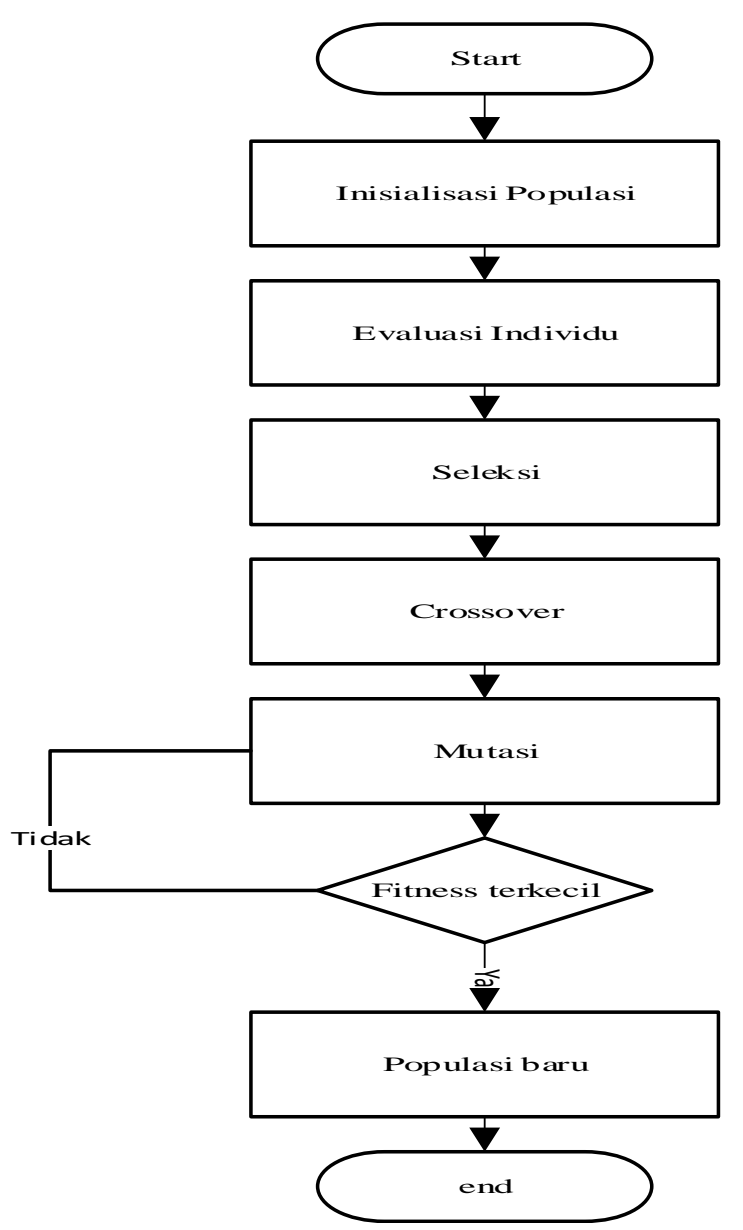

Gambar 2. Flowchart Algoritma Genetika 


\section{Hasil Dan Pembahasan}

\subsection{Evaluasi Konsumsi Energi}

Sebelum melakukan evaluasi intensitas energi1 6 harian, bulanan dan tahunan pada Gedung Fakultak2
7 Teknik Universitas Serambi Mekkah Propinsi Aceh, 8 ada baiknya dibahas tentang konsumsi listrik secara

9 riil berdasarkan pembayaran rekening listrik selama

10 setahun (dari bulan September 2016 s.d Agustus 2017). Data dapat dilihat pada tabel 1.

Tabel 1. Pemakaian listrik

\begin{tabular}{|c|c|c|c|c|c|}
\hline Tahun & Bulan & $\begin{array}{c}\text { Pembayaran } \\
\text { (per-bulan) }\end{array}$ & $\begin{array}{l}\text { Pemakaian } \\
\text { (per-bulan) }\end{array}$ & $\begin{array}{c}\text { Pemakaian [per- } \\
\text { bulan] }\end{array}$ & $\begin{array}{c}\text { Pemakaian (per } \\
\text { hari) }\end{array}$ \\
\hline 2016 & September & Ap. $\quad 2,533,990$ & $2,551 \mathrm{kWh}$ & $2,551,000 W h$ & $85,033 \mathrm{Wh}$ \\
\hline 2016 & Oktober & fip. $1,906,330$ & $1,917 \mathrm{kWh}$ & $1,917,000$ Wh & 63,900 Wh \\
\hline 2016 & November & Rp. $\quad 4,370,440$ & $4,407 \mathrm{kWh}$ & $4,407,000$ Wh & 146,900 Wh \\
\hline 2016 & Desember & Rp. $\quad 3,680,410$ & $3,709 \mathrm{kWh}$ & $3,709,000 \mathrm{Wh}$ & $123,633 \mathrm{Wh}$ \\
\hline 2017 & Januari & fip. $\quad 3,232,930$ & $3,257 \mathrm{kWh}$ & $3,257,000 \mathrm{Wh}$ & 108,567 Wh \\
\hline 2017 & Februari & Pe. $\quad 3,071,560$ & $3,094 \mathrm{kWh}$ & $3,094,000$ Wh & $103,133 \mathrm{Wh}$ \\
\hline 2017 & Maret & Rip. $\quad 2,539,930$ & $2,557 \mathrm{kWh}$ & $2,557,000 \mathrm{Wh}$ & 85,233 Wh \\
\hline 2017 & April & fip. $\quad 2,224,120$ & $2,238 \mathrm{kWh}$ & $2,238,000 \mathrm{Wh}$ & 74,600 Wh \\
\hline 2017 & Mei & Rp. $\quad 3,395,290$ & $3,420 \mathrm{kWh}$ & $3,420,000$ Wh & 114,000 Wh \\
\hline 2017 & Juni & Rp. $\quad 3,238,870$ & $3,264 \mathrm{kWh}$ & $3,264,000 \mathrm{Wh}$ & 108,800 Wh \\
\hline 2017 & Juli & fip. $\quad 2,450,830$ & $2,467 \mathrm{kWh}$ & $2,467,000 \mathrm{Wh}$ & $82,233 \mathrm{Wh}$ \\
\hline 2017 & Agustus & Po. $\quad 3,791,290$ & $3,821 \mathrm{kWh}$ & $3,821,000 \mathrm{Wh}$ & $127,367 \mathrm{Wh}$ \\
\hline
\end{tabular}

Berdasarkan tabel 1, maka menjelaskan tentang dokumentasi yang menampilkan informasi konsumsi listrik berdasarkan laporan keuangan bulanan berdasarkan rekening tagihan listrik bulanan selama setahun.

4.2. Peluang Hemat Energi

Tahap awal telah dilakukannya pengambilan data hasil IKE tahunan yang diperoleh dari rekening pembayaran listrik bulanan hinggan evaluasi (awal dan rinci), kemudian dikombinasikan dengan Algoritma Genetika (AG), sebelum diimplementasikan dengan menggunakan alat bantu sensor infrared guna mengontrol konsumsi daya harian. Maka perlu dilakukan penghematan energi utamanya adalah pada bagian yang menggunakan energi paling besar (90\%) dari kWh yang digunakan. Sumber tenaga yang dimaksud antara lain:

a. Air Contioning (AC); sebesar 52\% penggunaan, sebanyak 17 unit.

b. Personal Computer (PC); sebesar 25\% penggunaan, sebanyak 51 unit.

c. Kipas Angin; sebesar $13 \%$ penggunaan, sebanyak 50 unit.

Tabel 2 Rekapan Konsumsi Energi Ruang AC

\begin{tabular}{|r|l|r|r|r|r|}
\hline No & \multicolumn{1}{|c|}{ Ruangan } & Luas m2 & Daya (kW) & $\begin{array}{r}\text { Rata-rata } \\
\text { Jam/Hari }\end{array}$ & Energi (kWh) \\
\hline 1 & Ruang Akademik & 40 & 1,928 & 5,00 & 9,64 \\
\hline 2 & Ruang Dekan & 30 & 1,045 & 2,00 & 2,09 \\
\hline 3 & Ruang Dosen & 40 & 1,533 & 5,00 & 7,665 \\
\hline 4 & Ruang Lab-1 & 40 & 3,602 & 5,56 & 20,011 \\
\hline 5 & Ruang Lab-2 & 40 & 2,502 & 5,14 & 12,858 \\
\hline 6 & Ruang Lab-3 & 40 & 3,452 & 6,94 & 23,972 \\
\hline 7 & Ruang Lab-4 & 40 & 6,152 & 5,42 & 3,408 \\
\hline 8 & $\begin{array}{l}\text { Ruang Pembantu } \\
\text { Dekan }\end{array}$ & 20 & 0,852 & 4,00 & 4,785 \\
\hline 9 & Ruang Prodi-1 & 30 & 0,957 & 5,00 & 0,902 \\
\hline 10 & Ruang Prodi-2 & 30 & 0,902 & 1,00 & 12,95 \\
\hline 11 & Ruang Server & 4 & 1,85 & 7,00 & 323 \\
\hline
\end{tabular}




\begin{tabular}{|c|r|r|r|r|r|}
12 & Ruang Sidang & 32 & 1,624 & 1,00 & 1,624 \\
\hline Total & $\mathbf{3 8 6}$ & $\mathbf{2 6 , 3 9 9}$ & $\mathbf{5 3 , 0 6}$ & $\mathbf{1 3 3 , 2 2 8}$ \\
\hline
\end{tabular}

Analisis Peluang hemat energi (PHE) berdasarkan survey dan evaluasi yang dilakukan, maka PHE dapat dilakukan pada sisi jumlah jam penggunaan peralatan sumber tenaga dan penerangan berdasarkan efesiensi jumlah jam pemakaian. Setelah dikalkulasi maka disimpulkan bahwa ruangan yang mengkonsumsi energi paling besar adalah ruangan yang menggunakan $\mathrm{AC}$ dan akan dijadikan data untuk menghitung nilai optimasi dengan menggunakan Algoritma Genetika (AG) dengan harapan akan menjadi lebih optimal penggunaan energi listrik setelah dilakukan optimasi.

Proses optimasi yang dilakukan khusus untuk ruangan yang menggunakan AC saja, dengan data seperti pada Tabel 2.

Penggunaan Algoritma Genetika (AG)

Tahapan proses selanjutnya adalah mengoptimalkan pemakain energi listrik (kWh) dengan menggunakan metode Algoritma Genetika (AG), setelah mendapatkan hasil optimasi dengan menggunakan metode AG, maka hasil penerapannya akan menggunakan sensor infrared untuk mengontrol pemakain daya.
Algoritma Genetika digunakan untuk memperoleh optimasi penggunaan daya listrik dengan penjadwalan pemakaian daya yaitu sesuai kondisi yang terjadi ketika kombinasi antara jadwal perkuliahan secara keseluruhan, serta ketersediaan fasilitas dan ruang yang cukup untuk seluruh mata kuliah yang ada.

Terdapat berbagai aspek yang berkaitan dalam penggunaan daya listrik jika dikaitkan dengan penggunaan ruangan, diantaranya :

a. Pemakaian ruangan khusus bagi Pejabat FT (Dekan, Wakil Dekan dan Ketua Prodi)

b. Pemakaian ruangan khusus tenaga pengajar dan akademik (Dosen dan Administrasi)

c. Pemakaian ruangan khusus kuliah teori dan praktek (Ruang kuliah dan laboratorium)

d. Pemakaian ruangan khusus server dan bacaan.

e. Hari atau waktu dimana ruangan tidak digunakan.

Data optimasi energi listrik menggunakan algoritma genetika, memiliki 2 gen yaitu daya dan jam penggunaan ruangan, untuk datanya dapat dilihat pada tabel 3 .

Tabel 3. Variabel gen yang dimasukkan ke dalam Algoritma Genetika

\begin{tabular}{|r|l|c|c|}
\hline No & \multicolumn{1}{|c|}{ Ruangan } & Rata-rata Jam/Hari & Energi (kWh) \\
\hline 1 & Ruang Akademik & 5,00 & 9,64 \\
\hline 2 & Ruang Dekan & 2,00 & 2,09 \\
\hline 4 & Ruang Dosen & 5,00 & 7,67 \\
\hline 5 & Ruang Lab-1 & 5,56 & 20,01 \\
\hline 6 & Ruang Lab-3 & 5,14 & 12,86 \\
\hline 7 & Ruang Lab-4 & 6,94 & 23,97 \\
\hline 8 & $\begin{array}{l}\text { Ruang Pembantu } \\
\text { Dekan }\end{array}$ & 5,42 & 33,32 \\
\hline 9 & Ruang Prodi-1 & 4,00 & 3,41 \\
\hline 10 & Ruang Prodi-2 & 5,00 & 4,79 \\
\hline 11 & Ruang Server & 1,00 & 0,90 \\
\hline 12 & Ruang Sidang & 7,00 & 12,95 \\
\hline
\end{tabular}

Untuk mengoptimasi energi listrik dengan menggunakan algoritma genetika, maka langkah yang pertama di lakukan adalah inisialisasi populasi. Inisialisasi populasi awal merupakan proses penentuan variabel yang akan digunakan untuk dibangkitkan bilangan acak sejumlah kromosom yang akan digunakan untuk mencari solusi. Solusi / kromoson yang ditawarkan adalah 6 kromosom dengan gen masing-masing kromosom adalah 2 .
Sedangkan dalam setiap gen memiliki 2 parameter nilai yaitu energi dan jam. Dimana parameter ini berguna untuk mengecek nilai finess dari suatu kromosom.

\subsection{Hasil optimasi}

Setelah melakukan proses optimasi dengan menggunakan Algoritma Genetika, maka mendapatkan hasil seperti pada Tabel 4. 
Tabel 4. Proses optimasi dengan menggunakan Algoritma Genetika

\begin{tabular}{|c|c|c|c|c|c|c|c|}
\hline No & Ruang & $\begin{array}{l}\text { Energi } \\
\text { awal } \\
(\mathbf{k W h})\end{array}$ & $\begin{array}{l}\text { Eenergi } \\
\text { Optimasi } \\
(\mathbf{k w h})\end{array}$ & $\begin{array}{l}\text { Luas } \\
(\mathrm{m} 2)\end{array}$ & $\begin{array}{l}\text { IKE Awal } \\
\left(\mathbf{k W h} / \mathbf{m}^{2}\right)\end{array}$ & $\begin{array}{c}\text { IKE } \\
\text { Optimasi } \\
\left(\mathbf{k W h} / \mathbf{~ m}^{2}\right)\end{array}$ & $\begin{array}{c}\text { Persentase } \\
\text { Hemat } \\
\text { Energi }(\%)\end{array}$ \\
\hline 1 & Ruang Akademik & 0,400 & 0,134 & 40 & 0,010 & 0,003 & 33,60 \\
\hline 2 & Ruang Dekan & 0,364 & 0,184 & 30 & 0,012 & 0,006 & 50,65 \\
\hline 3 & Ruang Dosen & 0,611 & 0,345 & 40 & 0,015 & 0,009 & 56,47 \\
\hline 4 & Ruang Lab-1 & 0,320 & 0,122 & 40 & 0,008 & 0,003 & 38,30 \\
\hline 5 & Ruang Lab-2 & 0,427 & 0,060 & 40 & 0,011 & 0,001 & 14,03 \\
\hline 6 & Ruang Lab-3 & 0,326 & 0,248 & 40 & 0,008 & 0,006 & 75,96 \\
\hline 7 & Ruang Lab-4 & 0,551 & 0,405 & 40 & 0,014 & 0,010 & 73,52 \\
\hline 8 & $\begin{array}{l}\text { Ruang Pembantu } \\
\text { Dekan }\end{array}$ & 0,470 & 0,183 & 20 & 0,024 & 0,009 & 38,83 \\
\hline 9 & Ruang Prodi-1 & 0,414 & 0,029 & 30 & 0,014 & 0,001 & 7,04 \\
\hline 10 & Ruang Prodi-2 & 0,591 & 0,321 & 30 & 0,020 & 0,011 & 54,37 \\
\hline 11 & Ruang Server & 0,364 & 0,249 & 4 & 0,091 & 0,062 & 68,39 \\
\hline 12 & Ruang Sidang & 0,579 & 0,212 & 32 & 0,018 & 0,007 & 36,67 \\
\hline \multicolumn{7}{|c|}{ Rata-rata } & 45,65 \\
\hline
\end{tabular}

Tabel 5. Energi yang sudah di optimalkan

\begin{tabular}{|c|c|c|c|c|c|c|}
\hline No & Ruangan & $\begin{array}{c}\text { Energi } \\
(k W h) / H a r i\end{array}$ & $\begin{array}{c}\text { Energi } \\
(\mathbf{k W h}) / \text { Bulan }\end{array}$ & $\begin{array}{c}\text { Persentase } \\
\text { Hemat } \\
\text { Energi }(\%)\end{array}$ & $\begin{array}{c}\text { Energi } \\
\text { Optimum } \\
(\mathbf{k W h}) / \text { Hari }\end{array}$ & $\begin{array}{c}\text { Energi } \\
\text { Optimum } \\
(\mathbf{k W h}) / \text { Bulan }\end{array}$ \\
\hline 1 & Ruang Akademik & 9,64 & 231,36 & 33,60 & 6,40 & 153,62 \\
\hline 2 & Ruang Dekan & 2,09 & 50,16 & 50,65 & 1,03 & 24,75 \\
\hline 3 & Ruang Dosen & 7,67 & 183,96 & 56,47 & 3,34 & 80,08 \\
\hline 4 & Ruang Lab-1 & 20,01 & 480,27 & 38,30 & 12,35 & 296,31 \\
\hline 5 & Ruang Lab-2 & 12,86 & 308,58 & 14,03 & 11,05 & 265,28 \\
\hline 6 & Ruang Lab-3 & 23,97 & 575,33 & 75,96 & 5,76 & 138,30 \\
\hline 7 & Ruang Lab-4 & 33,32 & 799,76 & 73,52 & 8,82 & 211,74 \\
\hline 8 & $\begin{array}{l}\text { Ruang Pembantu } \\
\text { Dekan }\end{array}$ & 3,41 & 81,79 & 38,83 & 2,08 & 50,03 \\
\hline 9 & Ruang Prodi-1 & 4,79 & 114,84 & 7,04 & 4,45 & 106,76 \\
\hline 10 & Ruang Prodi-2 & 0,90 & 21,65 & 54,37 & 0,41 & 9,88 \\
\hline 11 & Ruang Server & 12,95 & 310,80 & 68,39 & 4,09 & 98,26 \\
\hline 12 & Ruang Sidang & 1,62 & 38,98 & 36,67 & 1,03 & 24,68 \\
\hline \multicolumn{2}{|c|}{ Total } & 133,23 & 3197,48 & 547,84 & 60,82 & 1459,70 \\
\hline \multicolumn{2}{|c|}{ Rata-rata } & 11,10 & 266,46 & 45,65 & 5,07 & 121,64 \\
\hline
\end{tabular}


Setelah dilakukan proses algoritma genetika (AG) maka didapat individu baru terbaik, kemudian total energi optimum yang diperoleh selanjutnya di substitusi ke dalam persamaan (2.1) untuk mendapatkan IKE optimal. Rata-rata persentase penghematan adalah sebesar 45,65\% mewakili untuk semua ruangan.

Penghematan energi yang ril dapat dihitung dari persentase hemat energi yang telah dihitung dengan menggunakan metode algoritma genetika dan hasilnya seperti tabel 5.

Berdasarkan hasil energi yang sudah di optimalkan pada Tabel 5 dapat dijelaskan dalam bentuk grafik sesuai pada Gambar 1 .

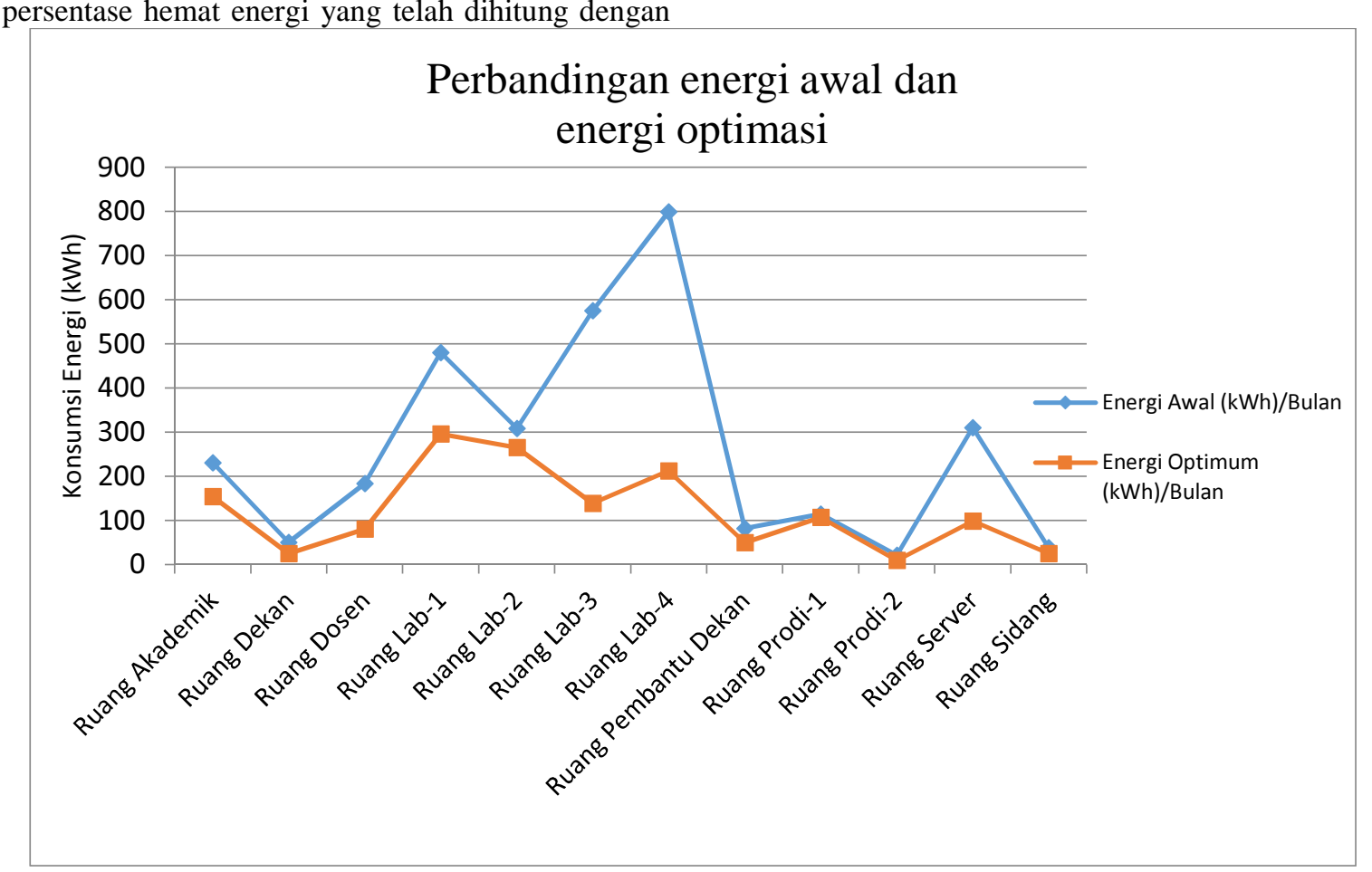

Gambar 1. Grafik hasil optimasi energi listrik

\section{Kesimpulan Dan Saran}

Berdasarkan hasil penelitian yang diperoleh, dapat diambil kesimpulan sebagai berikut :

1. Faktor yang mempengaruhi borosnya pemakaian energi adalah peralatan yang digunakan mengkonsumsi daya yang besar, menghidupkan peralatan listrik yang tidak sesuai dengan kebutuhan.

2. Setelah dilakukan optimalisasi dengan menggunakan metode algoritma genetika (AG) mendapatkan hasil penggunaan energi yang lebih optimal sebesar 45,65\% sesuai dengan IKE, dan juga memberikan Peluang Hemat Energi (PHE) dengan penerapan sensor infrared.

\section{Daftar Pustaka}

[1]. Ida Bagus Putra Setanu M, Rukmi Sari Hartati, I Nyoman Satya Kumara, "Pengelolaan Energi Listrik pada Gedung Fakultas Kedokteran Universitas UDAYANA Kampus Sudirman Denpasar," Denpasar. Desember 2012.

[2]. Menteri Energi dan Sumber Daya Mineral RI, "Peraturan Menteri Nomor 13 Tahun 2012 Tentang Penghematan Pemakaian Tenaga Listrik," Jakarta, 2012.
[3]. Yadi Mulyadi, Anggi Rizki, Sumarto, "Analisis Audit Energi Untuk Pencapaian Efisiensi Penggunaan Energi di Gedung FPMIPA-JICA Universitas Pendidikan Indonesia," vol. 12, no. 1, pp. 81-88, Bandung, Maret 2013.

[4]. SNI, "Prosedur Audit Energi Pada Bangunan Gedung," SNI 03-6196-2000, Jakarta, 2000.

[5]. D. S. Pasisarha, "Evaluasi IKE Listrik Melalui Audit Awal Energi Listrik di Kampus Polines," pp. 1-7, Semarang, April 2010.

[6]. B. Priyandono, "Analisis Konservasi Energi Listrik pada Rumah Tinggal Daya 2200VA dengan Beban Penerangan,” pp. 1-10, Bandung, 2014

[7]. Mahmudy, WF 2013, Algoritma Evolusi, Program Teknologi Informasi dan Ilmu Komputer, Universitas Brawijaya, Malang.

[8]. Munawir, TA,Gani, and Y, Away. "Implementasi Replacement Strategy Steady State Dan Generational Dalam Algoritma Berevolusi Untuk Penyelesaian Tsp." Karya Ilmiah Teknik Elektro 1, No. 1, 2016. 
